\title{
Differentiation of the 'Mycobacterium' rhodochrous-group from Nocardiae by $\beta$-Galactosidase Activity
}

\author{
By M. TSUKAMURA \\ The National Sanatorium, Chubu Chest Hospital, Obu, Aichi-ken, Japan 474
}

(Received 6 August I973; revised 3 September 1973)

\section{INTRODUCTION}

Gordon \& Mihm (1957; 1959) differentiated 'Mycobacterium' rhodochrous from the genus Nocardia and considered the taxon to be a member of the genus Mycobacterium. Later, Gordon (I966) reconsidered this classification, suggesting the organism occupied an intermediate position between Mycobacterium and Nocardia. The organisms are currently referred to as 'Mycobacterium' rhodochrous, the correct genus remaining undecided.

Tsukamura (197I) isolated a number of slightly acid-fast organisms, similar to 'Mycobacterium' rhodochrous but not identical, from sputa of patients with pulmonary disease and from soil, and proposed a new genus, Gordona, for them. Six species of the genus Gordona have been described: G. bronchialis (Tsukamura, Inagaki \& Kondo, 1970; Tsukamura, I97I); G. rubropertincta (synonym, G. rubra) (Tsukamura, I97I ; 1973); G. terrae (Tsukamura, I97I); G. aurantiaca (Tsukamura \& Mizuno, I97I); G. rhodochroa (Tsukamura, 1973); and G. rosea (Tsukamura, 1973). The last two species had previously been named ' $M$.' rhodochrous but have now been included in the new genus (Tsukamura, I97I); Tsukamura (I97I) described eight characters for distinguishing the genus Gordona from the genera Mycobacterium and Nocardia. The present study reports that the test for $\beta$-galactosidase activity is also useful for distinguishing the genus Gordona from the genus Nocardia. Because the genus Gordona is not yet generally accepted, it is called the 'rhodochrous-group' in the present study.

\section{METHODS}

A modification of the methods of Tacquet et al. (I966) and of Kubala (E. Kubala, personal communication) was used for testing $\beta$-galactosidase activity.

The basal medium contained: $\mathrm{KH}_{2} \mathrm{PO}_{4}$, I $\cdot 0 \mathrm{~g} ; \mathrm{Na}_{2} \mathrm{HPO}_{4}$. I $2 \mathrm{H}_{2} \mathrm{O}, 6 \cdot 25 \mathrm{~g} ; \mathrm{MgSO}_{4} \cdot 7 \mathrm{H}_{2} \mathrm{O}$, $0.6 \mathrm{~g}$; sodium citrate, $\mathrm{I} .5 \mathrm{~g}$; asparagine, $2.0 \mathrm{~g}$; $10 \%(\mathrm{v} / \mathrm{v})$ Tween 80 solution, $5.0 \mathrm{ml}$; and distilled water, $1000 \mathrm{ml}$, and was sterilized by autoclaving. To $100 \mathrm{ml}$ of this medium, O. I g of 2-nitrophenyl- $\beta$-D-galactopyranoside (BDH Chemicals, Poole, Dorset) was added, and the medium was sterilized by heating at $100{ }^{\circ} \mathrm{C}$ for $5 \mathrm{~min}$ in a water bath (the heating time should be exactly $5 \mathrm{~min}$ because excess heating produces a yellow colouring in the medium); the medium may also be sterilized by filtration. After cooling, bovine serum (Eiken Co., Japan, Tokyo) was added to give a final concentration of $4 \%(\mathrm{v} / \mathrm{v})$.

Tubes containing $5 \mathrm{ml}$ of the complete medium were inoculated with one loopful (about I $\mathrm{mg}$ ) of test organism and incubated at $28{ }^{\circ} \mathrm{C}$ for 7 days. A positive reaction was indicated by a yellow coloration not evident in the uninoculated control tube. The readings were clear-cut and reproducible. In three replications made at different times, all the rhodochrousgroup test strains, except two strains of Gordona bronchialis, showed the same reaction. 
Table I. $\beta$-Galactosidase activity of nocardiae, rhodochrous-group (Gordona) organisms and rapidly growing mycobacteria

$N$. asteroides

$N$. brasiliensis

$N$. caviae

$N$. farcinica

N. rubra*

$N$. pelletieri

N. madurae $\dagger$

G. rhodochroa

G. bronchialis

G. rubropertincta (G. rubra)

G. terrae

G. rosea§

G. aurantiaca

M. smegmatis

M. phlei

$M$. chelonei subsp. chelonei

$M$. chelonei subsp. abscessus

$M$. fortuitum

M. chitae

M. vaccae

$M$. aurum

$M$. parafortuitum

$M$. rhodesiae

M. neoaurum

M. aichiense

M. chubuense

M. flavescens

M. thermoresistibile

$\begin{array}{cc}\text { No. of } & \text { No. of } \\ \text { strains } & \text { strains } \\ \text { showing a } & \text { showing a } \\ \text { positive } & \text { negative } \\ \text { reaction } & \text { reaction }\end{array}$

$\begin{array}{rr}14 & 0 \\ 9 & 0 \\ 8 & 0 \\ 34 & 0 \\ 2 & 4 \\ 0 & 5 \\ 1 & 3 \\ 0 & 10 \\ 2 & 31 \\ 0 & 14 \\ 0 & 14 \\ 0 & 2 \\ 4 & 0 \\ 20 & 0 \\ 16 & 5 \\ 20 & 0 \\ 19 & 1 \\ 0 & 20 \\ 0 & 6 \\ 0 & 13 \\ 3 & 33 \\ 0 & 13 \\ 3 & 18 \\ 1 & 19 \\ 0 & 8 \\ 2 & 16 \\ 0 & 10 \\ 0 & 10\end{array}$

* Strains M6 and M75 showed a positive reaction, and strains MI, MI03, MI9I and MI92 showed a negative reaction.

† Strain R43 I showed a positive reaction, and strains R706, RIO9I and RI260 showed a negative reaction.

$\$$ Ten strains of $G$. rhodochroa were received as ' $M$.' rhodochrous: ATCC I4348; ATCC 400I; ATCC 999; ATCC I4349; ATCC I434I; ATCC 4276; ATCC 4273; ATCC I4347; N3I (M. Goodfellow); ATCC I 3808.

$\S$ Two strains of $G$. rosea were received as ' $M$.' rhodochrous: ATCC 27I : ATCC 4004 .

\section{RESULTS AND DISCUSSION}

Five of the six species of the genus Gordona (the rhodochrous-group), including all strains received as ' $M$.' rhodochrous, showed a negative reaction in the test (Table I). Only G. aurantiaca showed a positive reaction. Unlike the others, this species was acidfast with orange pigmented colonies, and had been regarded as an outsider of the group (Tsukamura \& Mizuno, I97I).

All 'true' nocardiae, Nocardia asteroides, $N$. brasiliensis and $N$. caviae, showed a positive reaction. Therefore the rhodochrous-group could be differentiated from the Nocardia by its absence of $\beta$-galactosidase activity.

Nocardia pelletieri and N. madurae showed a negative reaction. These two species had been distinguished from the 'true' nocardiae as 'streptomyces-like' nocardiae (Schneidau 
\& Shaffer, 1957; 1960) and have been included in a different genus, Actinomadura (Lechevalier \& Lechevalier, 1970). Nocardia farcinica showed a positive reaction. A group of strains received as nocardiae and provisionally classified as the species Nocardia rubra (Tsukamura, 1969) showed different reactions.

Rapidly growing mycobacteria were separated into two subgroups: Mycobacterium smegmatis, $M$. phlei and $M$. chelonei showed a positive reaction; $M$. fortuitum, $M$. chitae, $M$. thermoresistibile, $M$. flavescens, $M$. vaccae, $M$. aurum, $M$. parafortuitum, and the recently defined, rapidly growing, scotochromogenic mycobacteria, $M$. rhodesiae, $M$. neoaurum, M. aichiense and $M$. chubuense, gave a negative reaction.

The test for $\beta$-galactosidase activity is useful for differentiating the rhodochrous-group (the genus Gordona) from the genus Nocardia.

\section{REFERENCES}

GoRdon, R. E. (1966). Some strains in search of a genus - Corynebacterium, Mycobacterium, Nocardia or what? Journal of General Microbiology 43, 329-343.

Gordon, R. E. \& Mirm, J. M. (I957). A comparative study of some strains received as nocardiae. Journal of Bacteriology 73, I5-27.

Gordon, R. E. \& MiHM, J. M. (1959). A comparison of four species of mycobacteria. Journal of General Microbiology 21, 736-748.

Lechevalier, H. A. \& Lechevalier, M. P. (1970). A critical evaluation of the genera of aerobic actinomycetes. In The Actinomycetales, pp. 393-405. Edited by H. Prauser. Jena: Gustav Fischer.

Schneidau, J. D., Jun. \& Shaffer, M. F. (1957). Studies on Nocardia and other Actinomycetales. I. Cultural studies. American Review of Respiratory Diseases 76, 770-788.

Schneidau, J. D., Jun. \& Shaffer, M. F. (1960). Studies on Nocardia and other Actinomycetales. II. Antigenic relationships shown by slide agglutination tests. American Review of Respiratory Diseases 82, $64-76$.

Tacquet, A., Tison, F., Polspoel, B., Roos, P. \& Devulder, B. (I966). Étude de la $\beta$-D-galactosidase des mycobactéries (Note préliminaire). Annales de l'Institut Pasteur III, 86-89.

Tsuramura, M. (1969). Numerical taxonomy of the genus Nocardia. Journal of General Microbiology 56, $265-287$.

Tsukamura, M. (1971). Proposal of a new genus, Gordona, for slightly acid-fast organisms occurring in sputa of patients with pulmonary disease and in soil. Journal of General Microbiology 68, 15-26.

Tsukamura, M. (1973). A taxonomic study of strains received as 'Mycobacterium' rhodochrous. Description of Gordona rhodochroa (Zopf; Overbeck; Gordon et Mihm) Tsukamura comb. nov. Japanese Journal of Microbiology 17, 189-197.

Tsukamura, M., INAGAKI, H. \& Kondo, H. (1970). A case report on a patient with pulmonary disease excreting frequently 'Mycobacterium' rhodochrous-like organisms. Kekkaku 45, 153-157.

Tsukamura, M. \& Mizuno, S. (197I). A new species of Gordona, Gordona aurantiaca, occurring in sputa of patients with pulmonary disease. Kekkaku 46, 93-98. 